\title{
PRELIMINARY COMMENT ON DAMAGE TO BUILDINGS IN THE INANGAHUA EARTHQUAKE
}

Bruce H. Falconer*

\section{Foreword}

This paper is presented for discussion at the N.Z.I.E. Conference in February 1969; and it appears as a prelude to the publication, in a special Bulletin of the Society, of a Preliminary Report on the Inangahua Earthquake from an overall viewpoint with contributions by many authors. Time available, and the sequence of publication, has not permitted the preparation of a detailed technical report upon building damage at this stage. This paper reviews, primarily, building damage near the epicentre, and includes a set of 36 photographs taken by the author at Murchison, Inangahua and Reefton.

\section{The earthquake}

The Inangahua earthquake of 5.24 am on May 24,1968 is reported ${ }^{1}$ to have a Magnitude of $\mathrm{M}_{\mathrm{L}}=7.0$, a shallow depth assumed provisionally at $12 \mathrm{~km}$, and an instrumental epicentre in unoccupied wooded country about $15 \mathrm{~km}$ north of the road and rail township of Inangahua Junction. The macroseismic effects include a fault movement ${ }^{2}$, landslides, ground fissures, subsidences, ejection of sand on some river terraces; and damage to roads, railway lines, bridges and buildings. From those effects a felt intensity of M.M.X has been assigned. The macroseismic epicentre appears to lie in the vicinity of Inangahua Junction and Camp. However, the nature of the terrain, and the alluvial deposits in the Buller and Inangahua River valleys at the locality, perhaps predispose such an estimate.

\section{Area of major damage}

The main shock at 5.24 am caused severe damage to buildings in an area from Stitt's Bluff (Berlin's) and Inangahua Landing to Inangahua Junction (distances of $10 \mathrm{~km}$ and $8 \mathrm{~km}$ ) and upstream from the Junction to Lyell (distance of $11 \mathrm{~km}$ ). That area is included within the zone of M.M.X intensity, and in which it has been estimated provisionally, that damage to buildings amounted to about half the value of buildings in the area. For that reason, and in view of the fact that the residents there were being evacuated from the damaged houses, together with loss of road access initially, an immediate recommendation was made on May 25 that the Government treat the above mentioned area as a special area for restoration of buildings.

\section{Other areas of damage}

Outside the special area of major damage, the incidence of damage decreased with distance, first rapidly from $10 \mathrm{~km}$ to $15 \mathrm{~km}$ to $20 \mathrm{~km}$ from Inangahua Junction, and then progressively more slowly with further distance. Nevertheless, the incidence or extent of damage was prominent where building construction was clearly vulnerable, or where the ground conditions favoured earth movement of landslip or subsidence, on the vibrational response of soft soils.

At the nearest towns - Murchison, Westport and Reefton - all at about $30 \mathrm{~km}$ from Inangahua Junction the incidence of damage had become selective. The type of damage included: collapses of brittle chimneys, cracking of weak masonry, fracture of some 
windows, tearing or wrinkling of wall paper at wall junctions, and spilling of contents of stores. In each of the three towns there was relatively little damage to buildings which would comply with accepted standards of earthquake resistant design of structures. The buildings that were damaged generally all had some obvious inherent weakness. Several masonry buildings in Westport suffered a renewal or re-exposure of earlier damage in the 1929 and 1962 earthquakes.

Toward the south, in Runanga and Greymouth, the incidence of chimney damage remained high. Age, weaknesses of mortar, and prior accumulated damage through use and heat, had left many chimneys vulnerable, which distant chimneys may have been undamaged by the $M_{L}=6$ Westport earthquake of 1962. In Greymouth there are many commercial buildings with unreinforced masonry bearing walls, with timber floors and roofs, which are poorly compartmented or braced for seismic resistance. The earthquake caused movements or spalling of plaster at old cracks, and some new cracks.

Toward the north, from Inangahua, the incidence of damage decreased steadily. In Nelson the prime source of damage was the cracking of domestic chimneys, and some cracking of the brickwork of old masonry commercial buildings. To the east in Canterbury damage was minor, principally the occasional cracking on movement of domestic chimneys.

More explicit comment will be given by others in the special Bulletin.

\section{Inangahua special area}

Within the area of the M.M.X isoseismal are the settlements of Inangahua Camp and Inangahua Junction comprising a township of some 50 houses, a school, post office, two churches, hotel, motel, petrol station, tea room and shop. Most of the dwellings in the township are state owned. In the farmland of the rest of the area of prime damage are some 30 farm dwellings with ancillary stores, milking sheds and implement sheds.

All dwellings in the area are timber framed. External walls are of weather board, except for two Electricity Department houses with brick veneer walls. Roofs are of galvanised iron sheeting, except for eight state owned houses having tile roofs. Relatively few buildings had sound foundations, such as timber base plates of walls bolted to a continuous concrete foundation strip around the perimeter. The farm dwellings, and most non-government built dwellings, generally were supported by an array of free standing timber piles. Many such structures moved sideways as the timber piles folded over from vertical to horizontal. Differential movements occurred in most cases.

Severe damage occurred to unreinforced brick or concrete block chimneys, either because of inherent weakness of the material, or because the chimney bases were brittle and provided greater rigidity for lateral movements than did the foundations. Many external chimneys collapsed completely to rubble. Several internal chimneys with poorly bonded bricks, in addition to collapsing above the roof line, spread laterally within the confined space bulging the building walls locally. There were no buildings with masonry bearing walls, other than two minor farm sheds with unreinforced concrete block perimeter walls in which the mortar was effectively unbonded to the blocks. The block walls collapsed.

\section{Photographs}

Nine pages are appended, with 36 photographs and with captions. Of these figures 5 to 32 are of damage in the Inangahua area.

1, 2, reference to special Bulletin. 


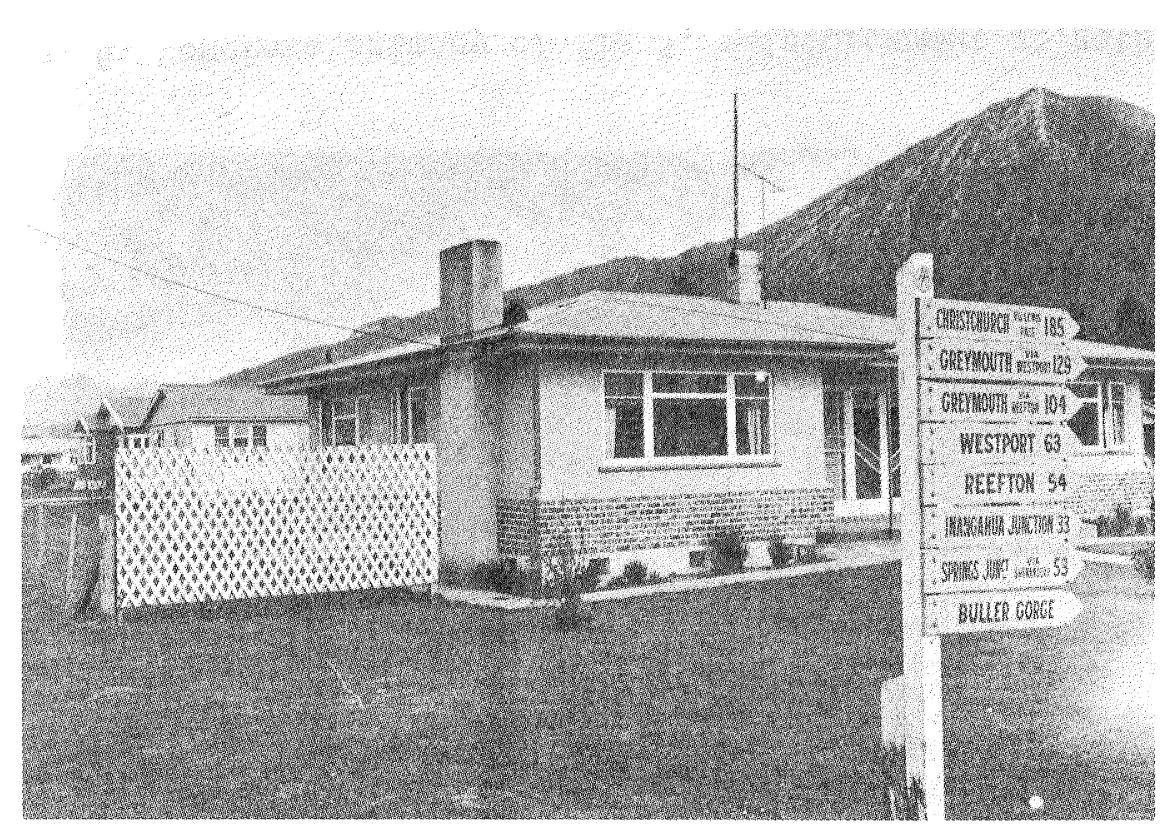

Fig 1. House in Murchison (August 1968)

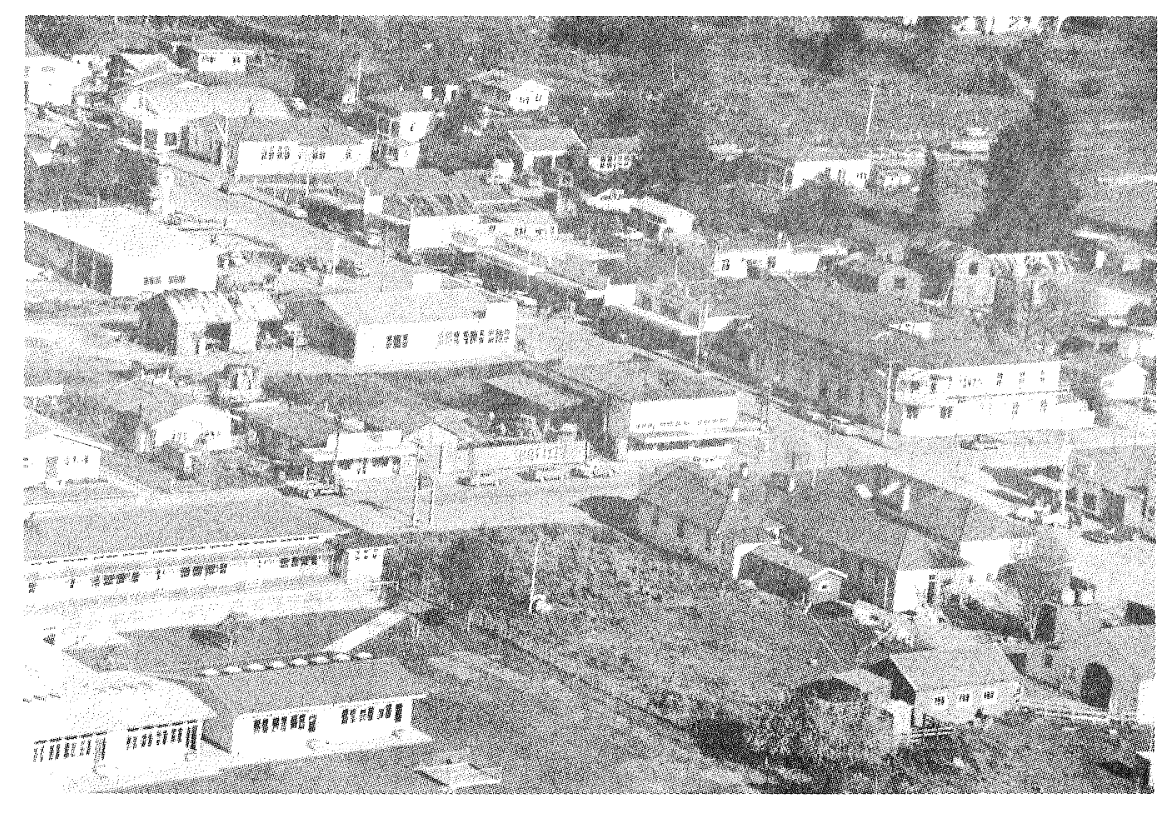

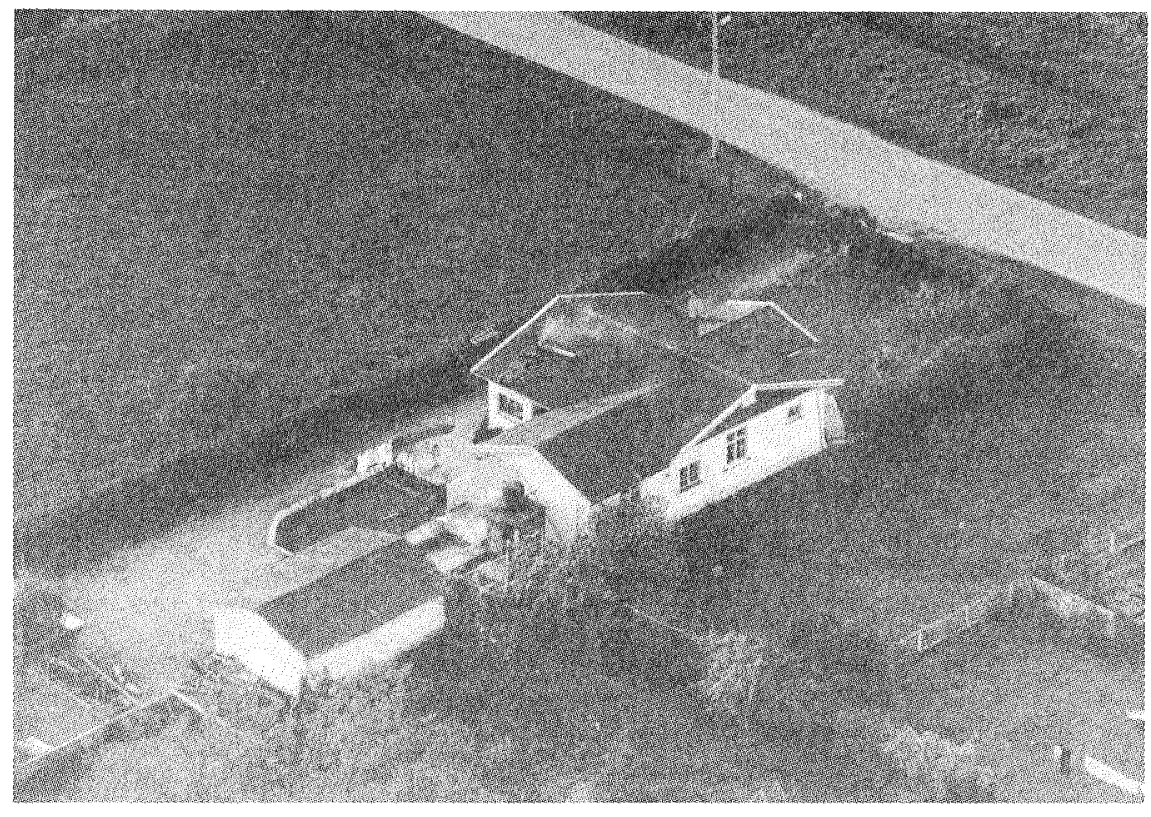

Fig. 3. Dwelling, collapsed chimney, May 24, 1968

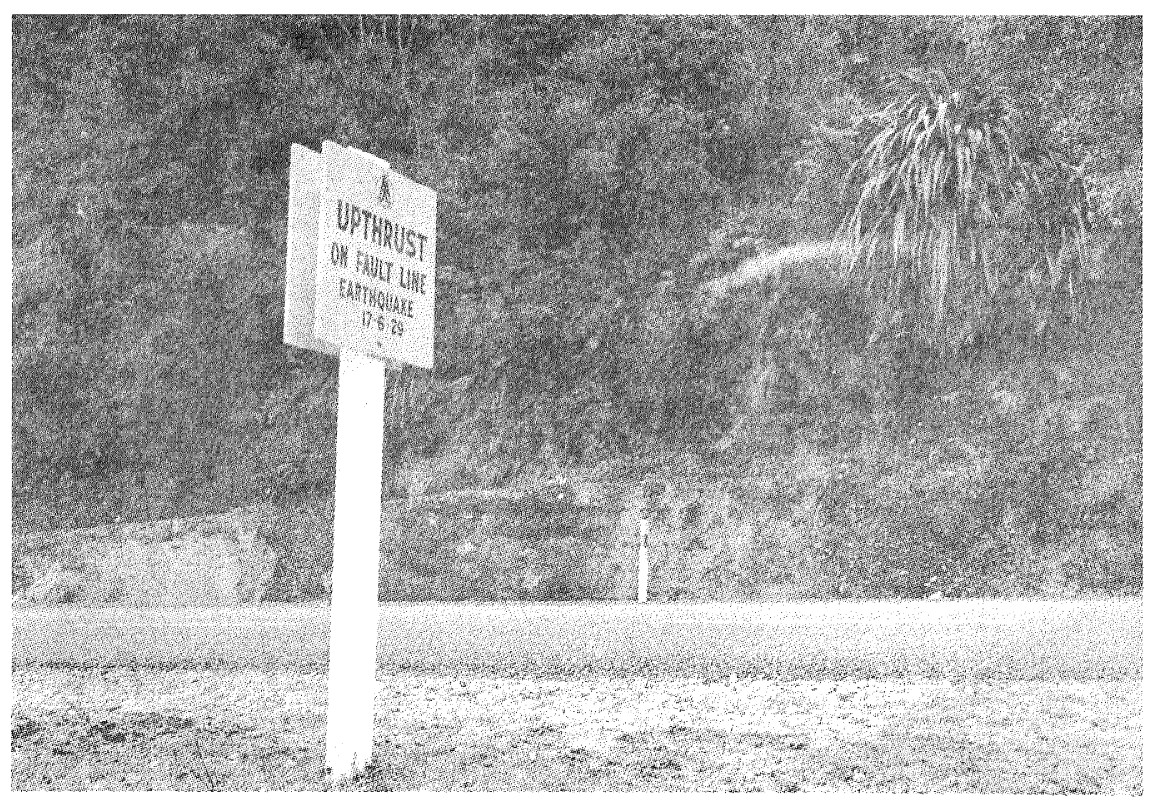

Fig 4. White Creek Fault, (1929 earthquake) 


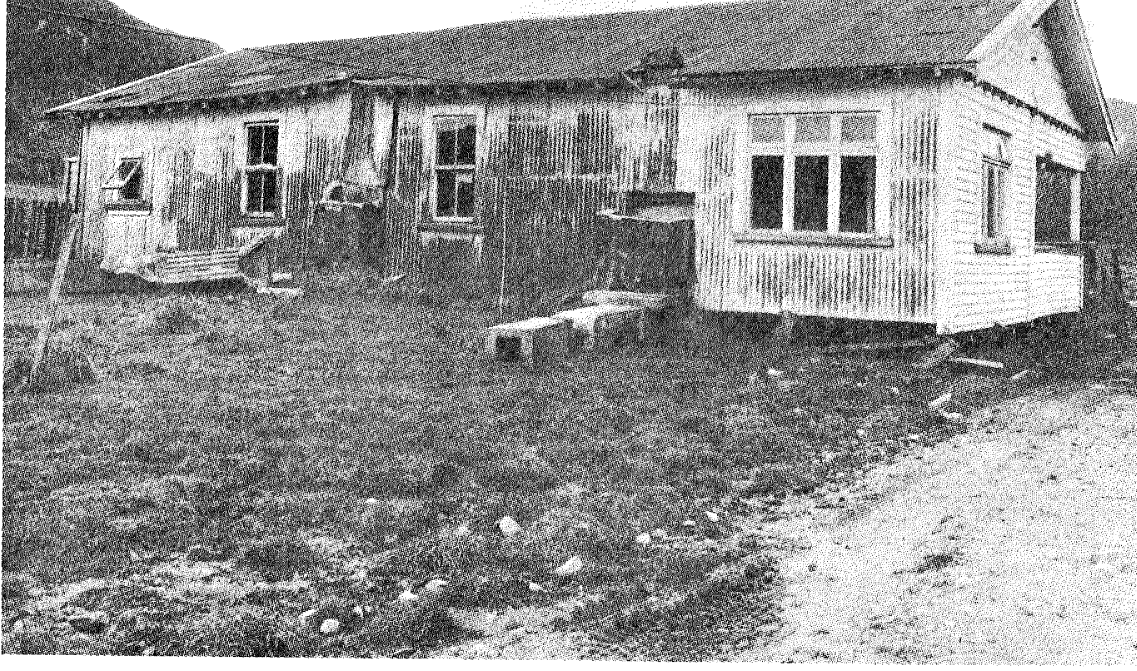

Fig. 5. Dwelling, off piles, chimneys down, $3 \mathrm{~km} \mathrm{n.w.} \mathrm{of} \mathrm{Lyell}$

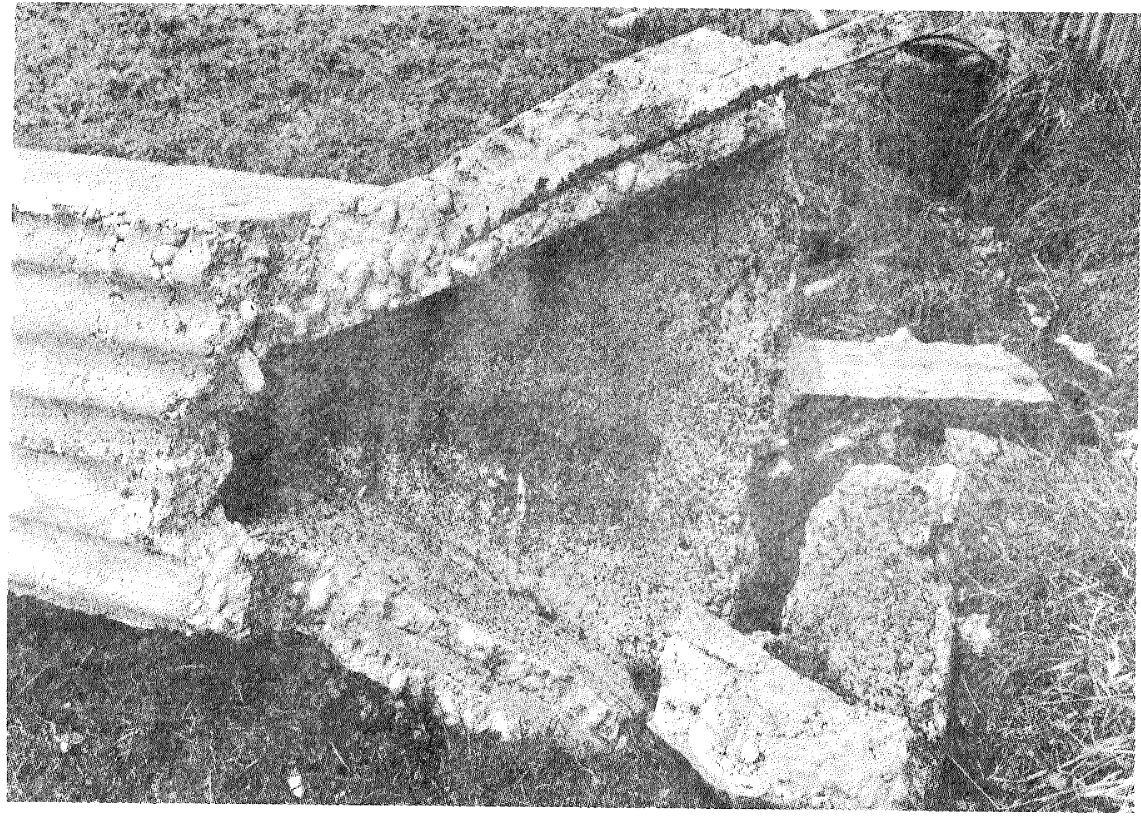

Fig. 6. Concrete chimney of fig 5, reinforcement at gathering

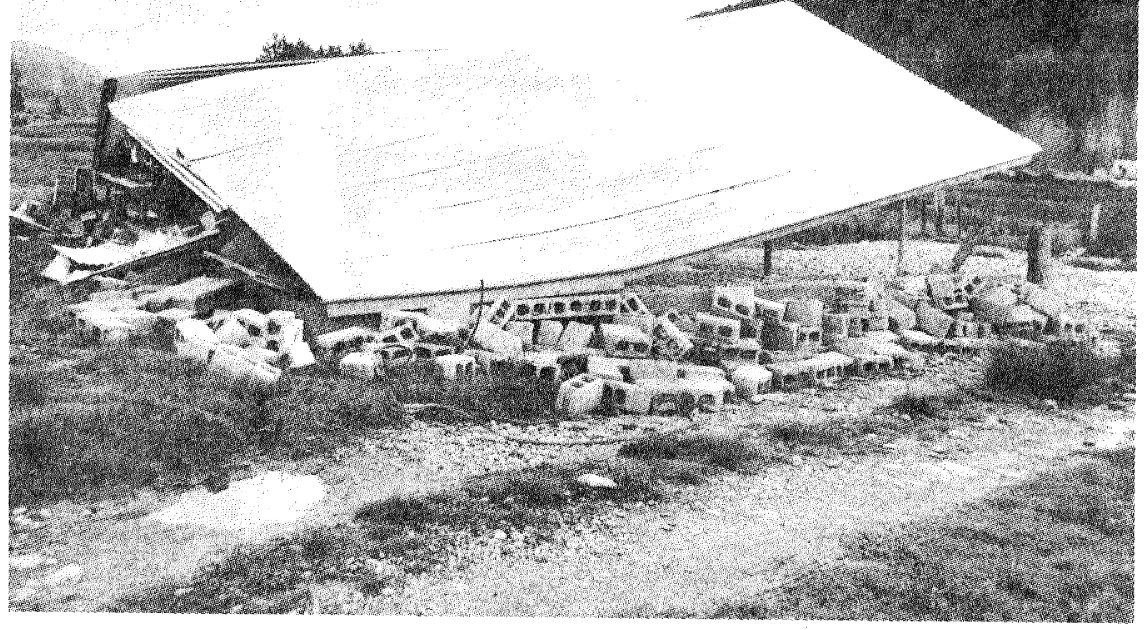

Fig 7. Farm shed, weak unreinforced concrete block walls

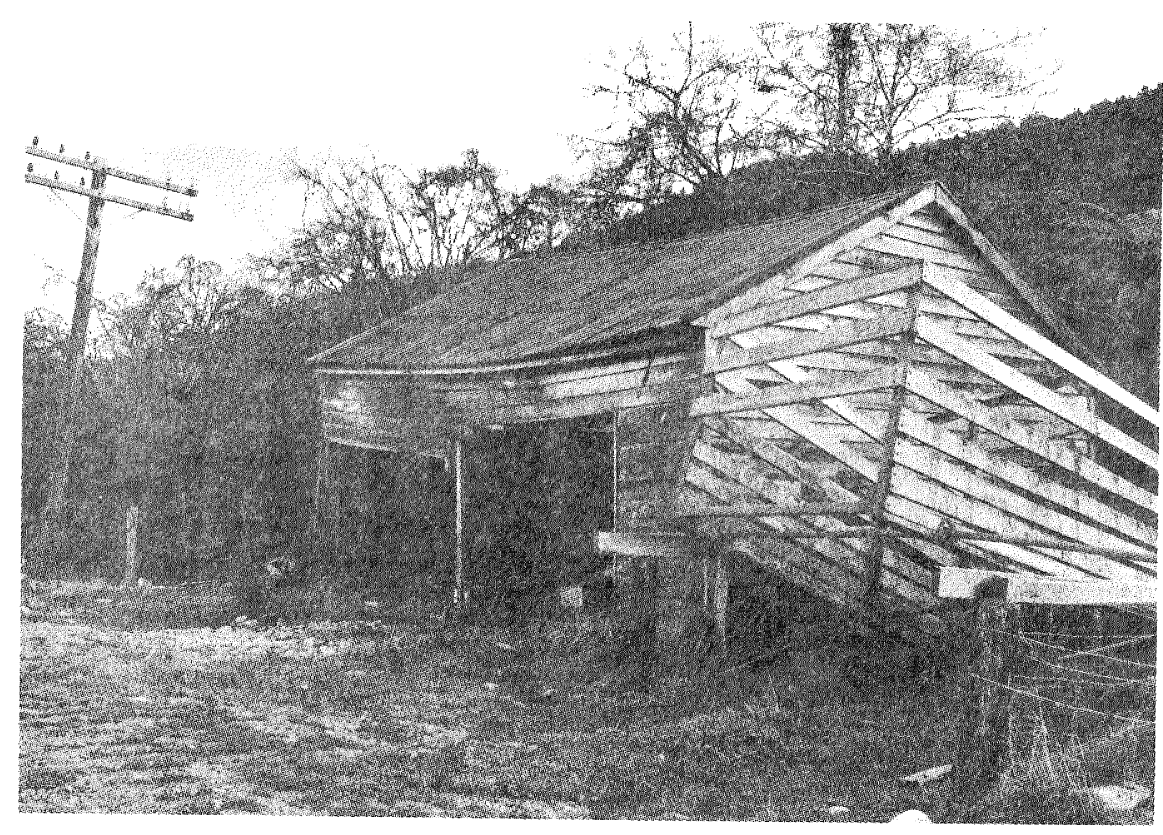

Fig. 8. Undamaged timber farm shed, derelict, near fig. 7 


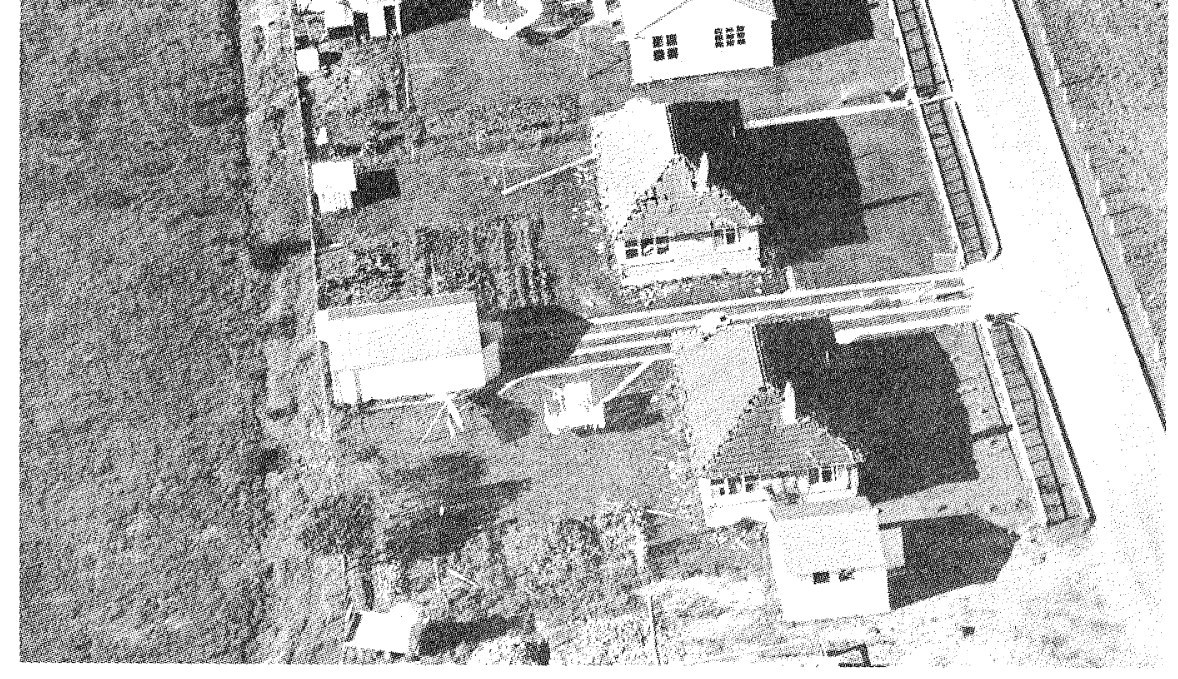

Fig 9. Dwellings 2, Inangahua Camp, tiles \& brick veneer

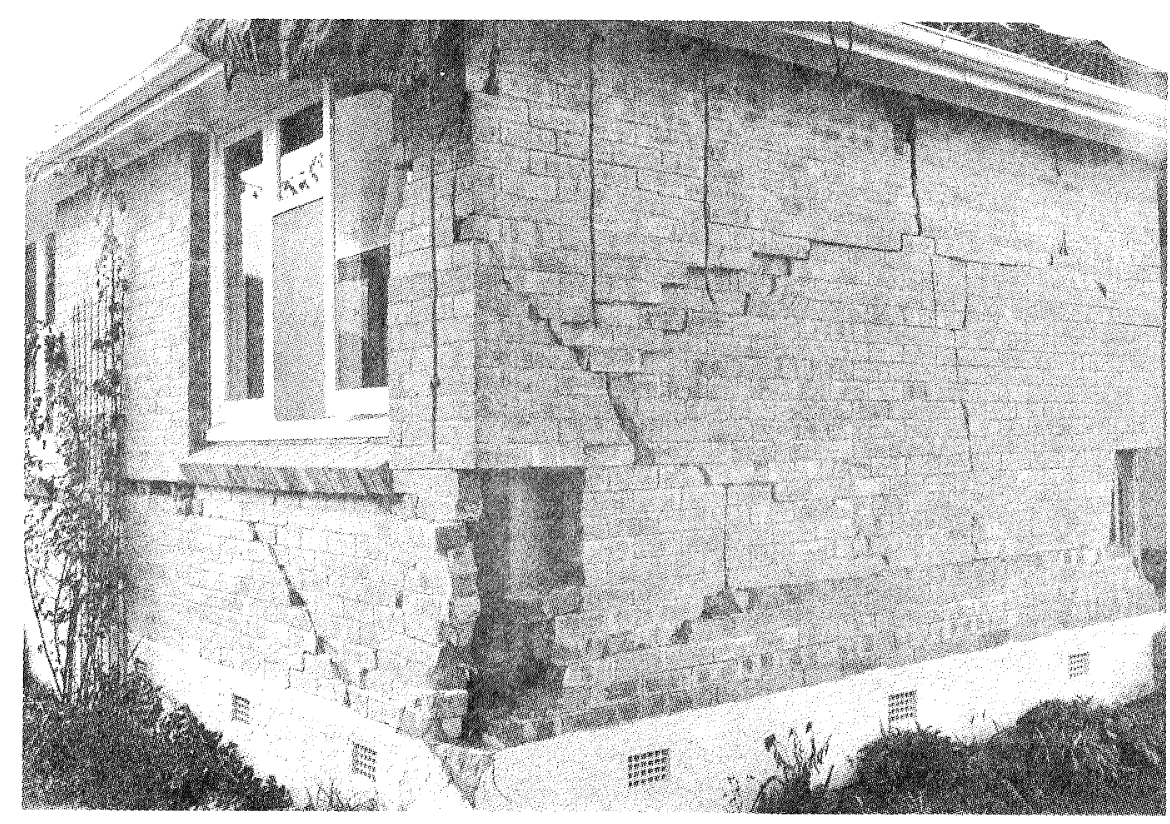

Fig. 10. Shattered veneer, lst dwelling, fig 9

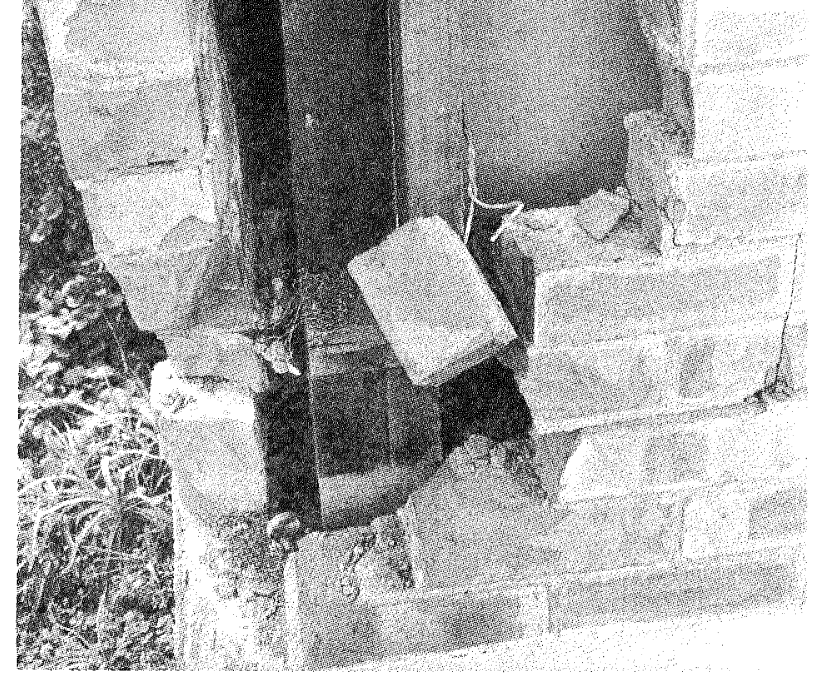

Fig. 11. Detail at bottom of fig. 10, one brick moved

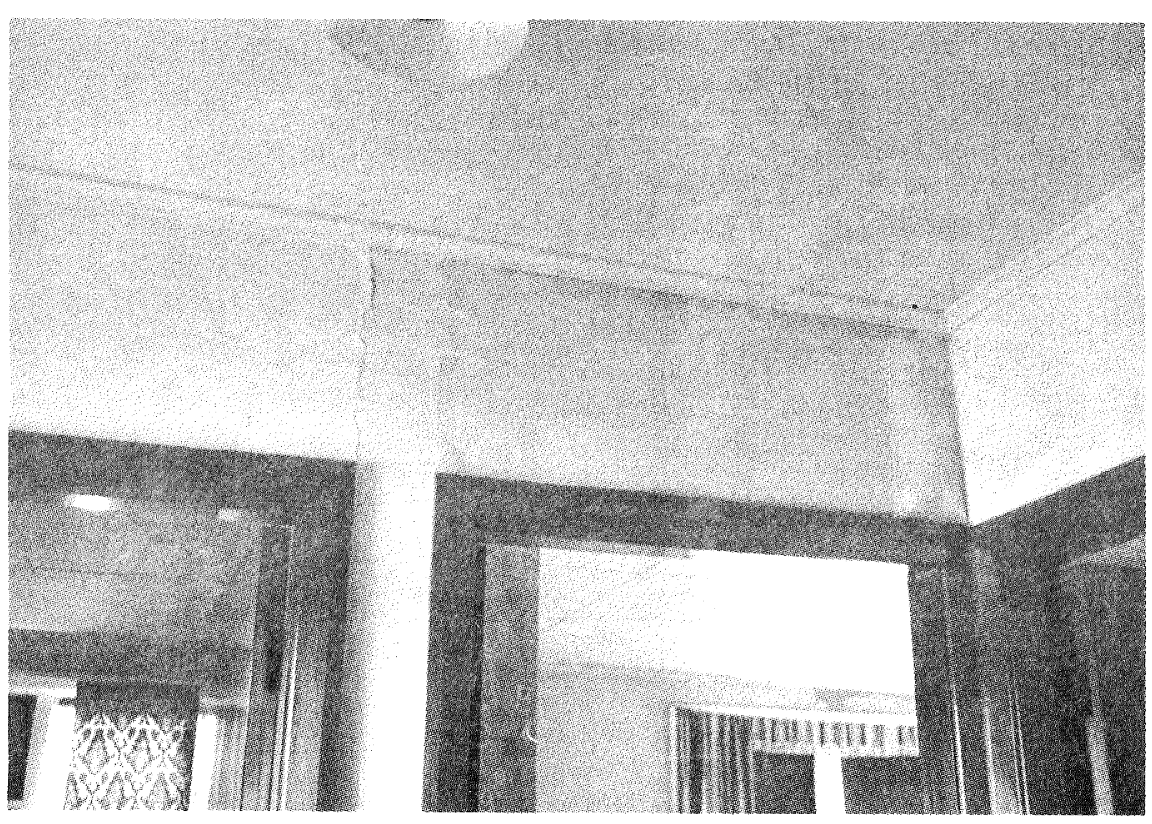

Fig. 12. Interion of fig. 10, moderate damage to lining 


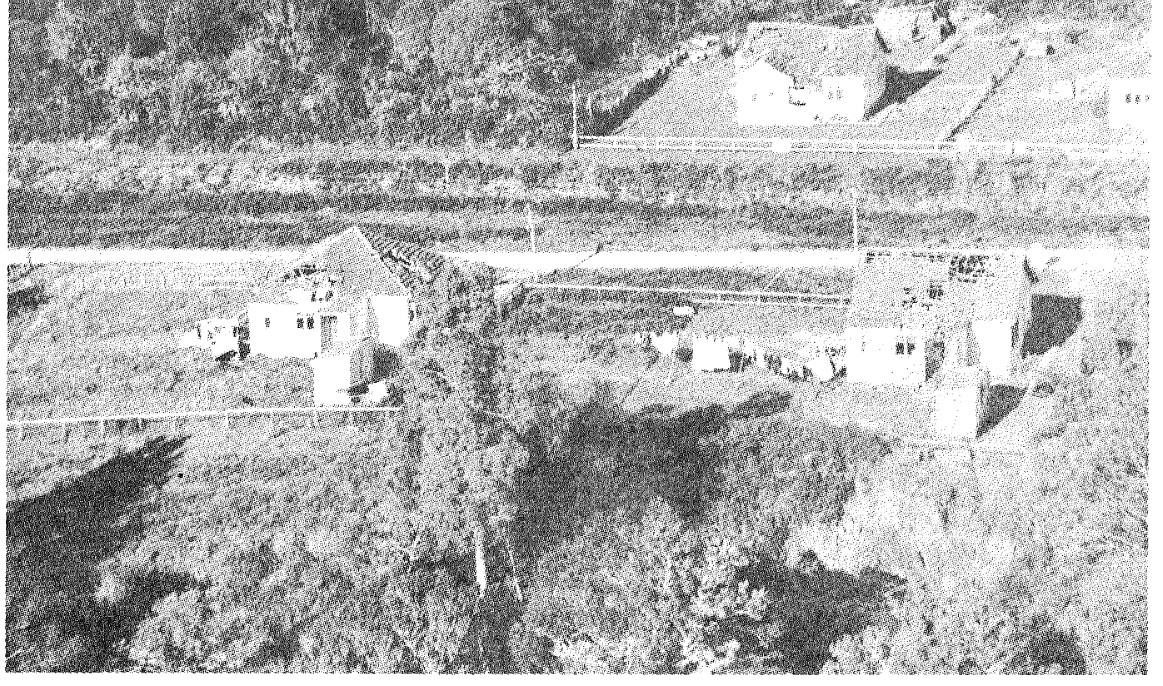

Fig. 13. Dwellings, Inangahua Camp,

tiles \& weather board

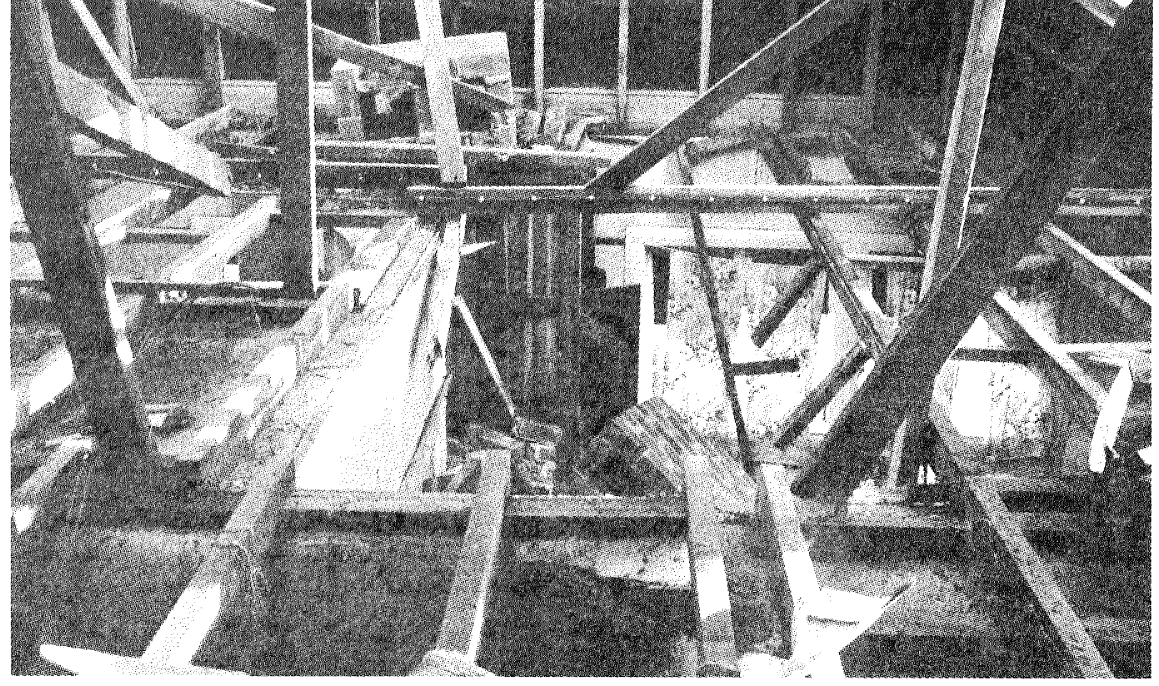

Fig. 15. View inside ceiling of fig 14, full collapse chimney
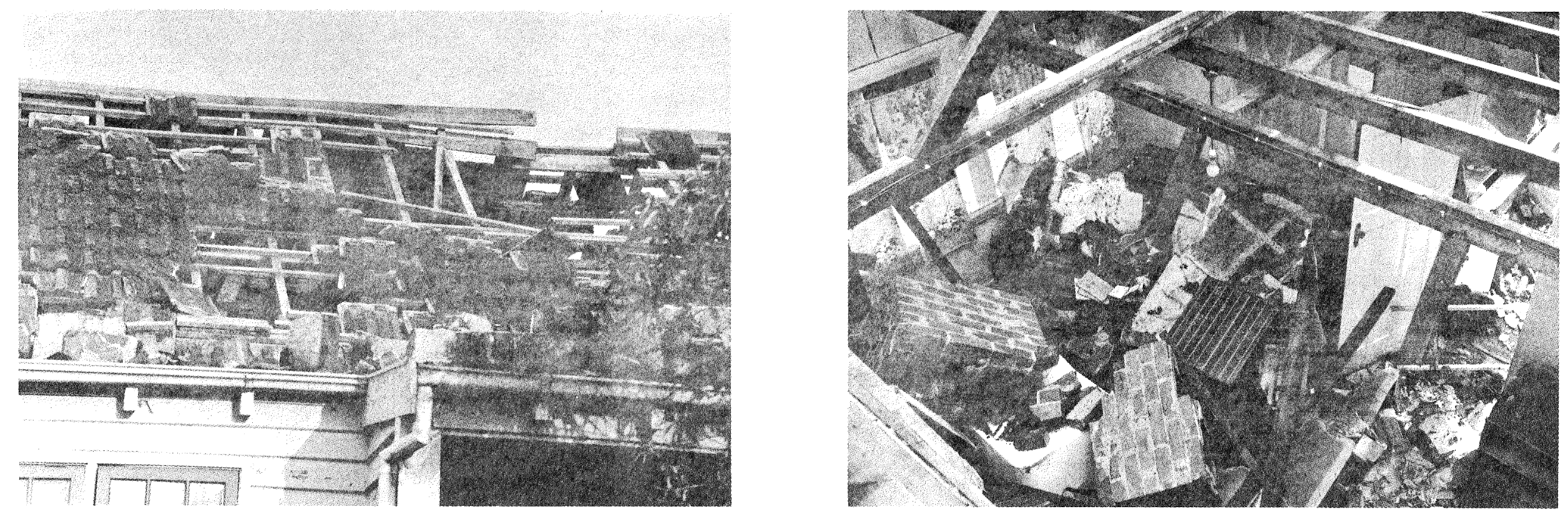

Fig. 14. dwelling lower right fig. 13, close up view of roof

Fig. 16. Debris of tiles and chimney on living room furniture 


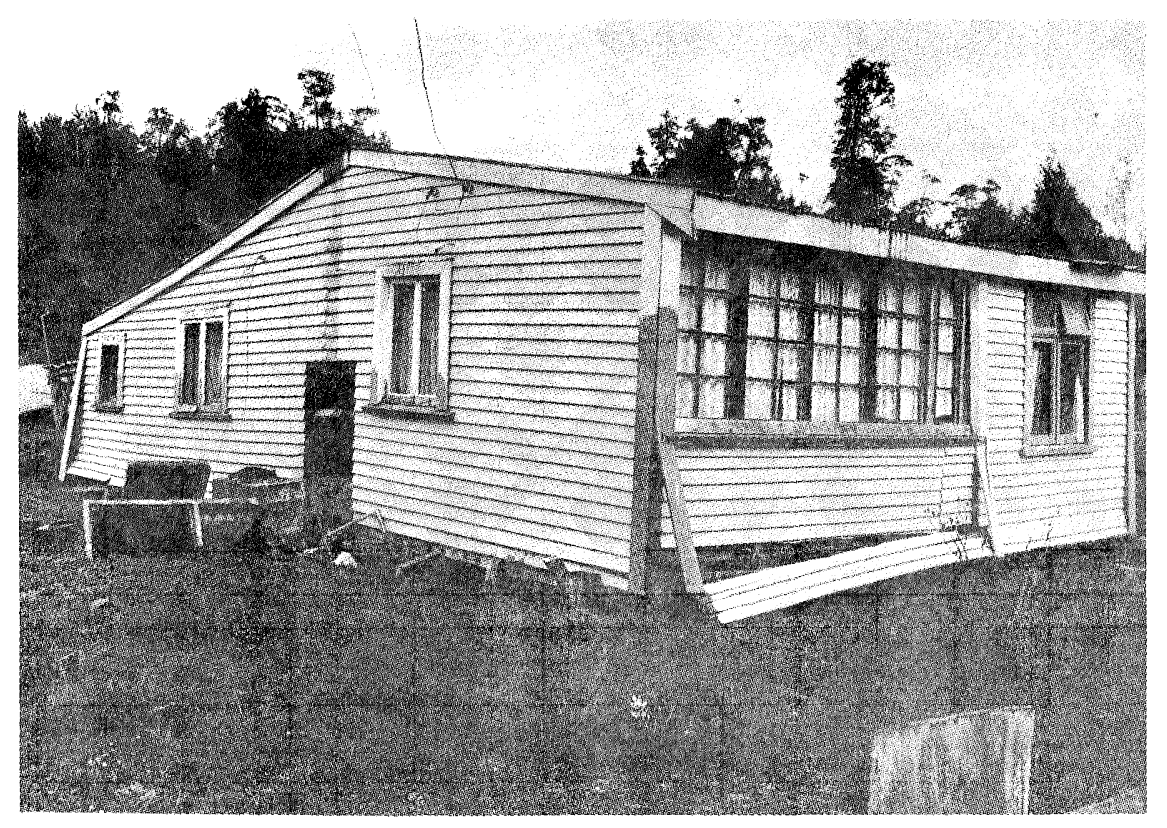

Fig. 17. Dwelling, Inangahua Camp, off piles, chimney down

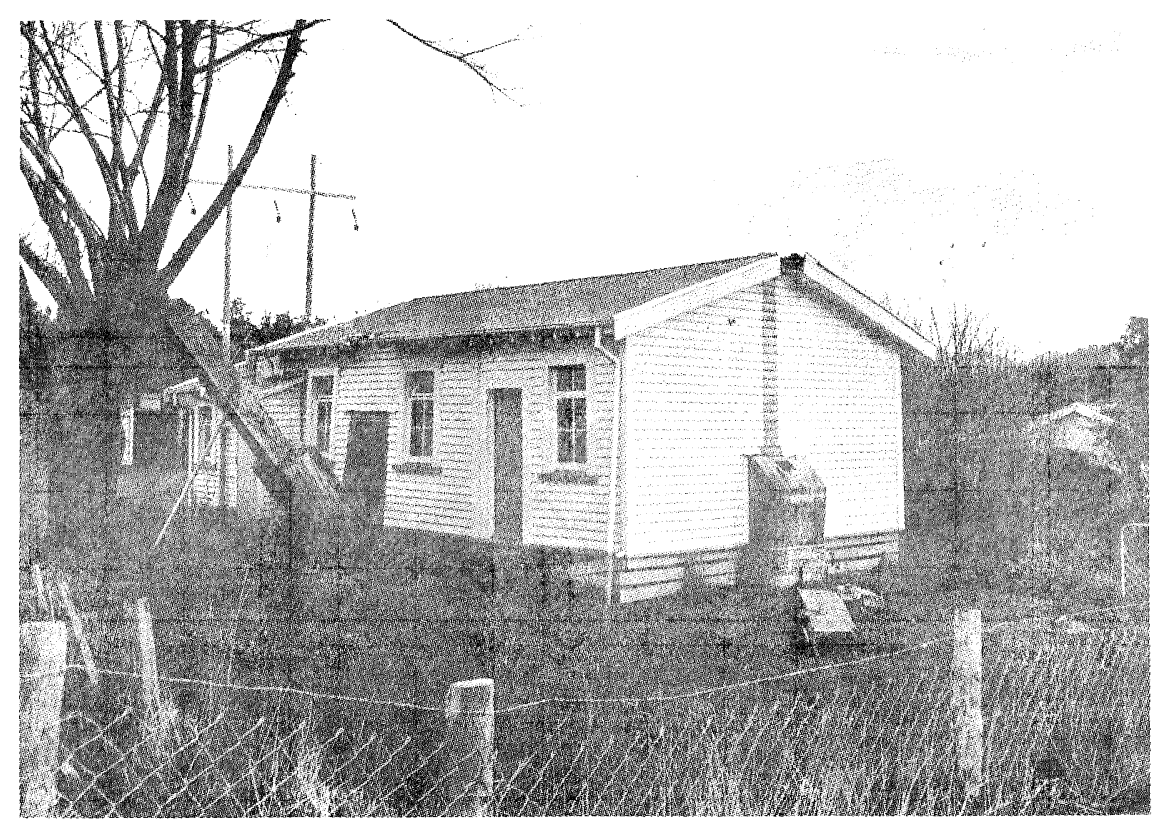

Fig. 18. Dwelling, one chimney folded out, another collapsed

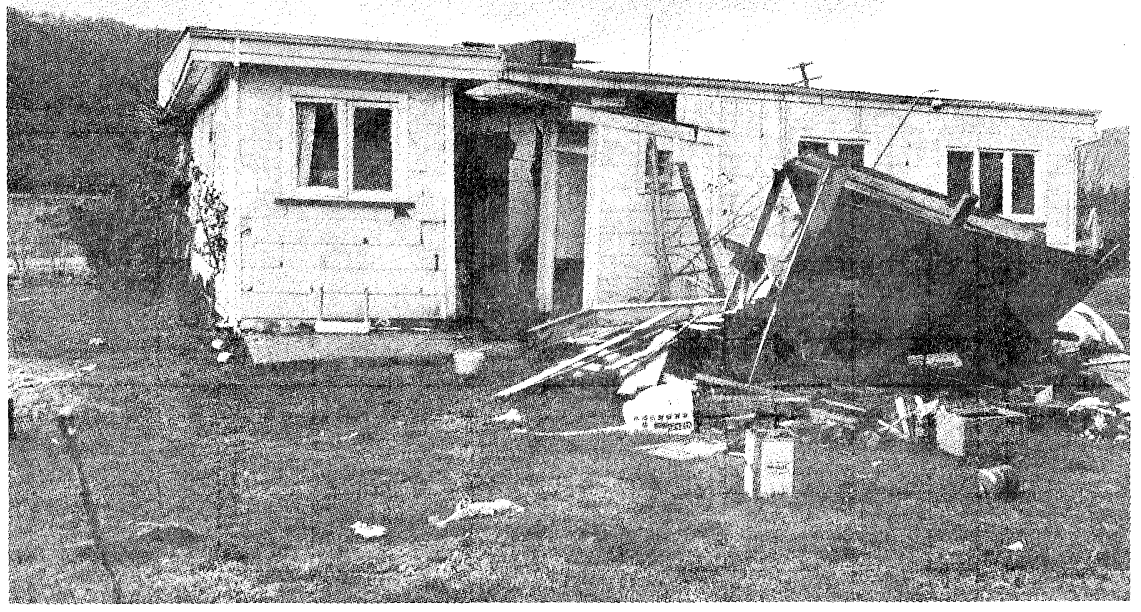

Fig. 19. Dwelling, moved, chimney collapsed, shed collapsed

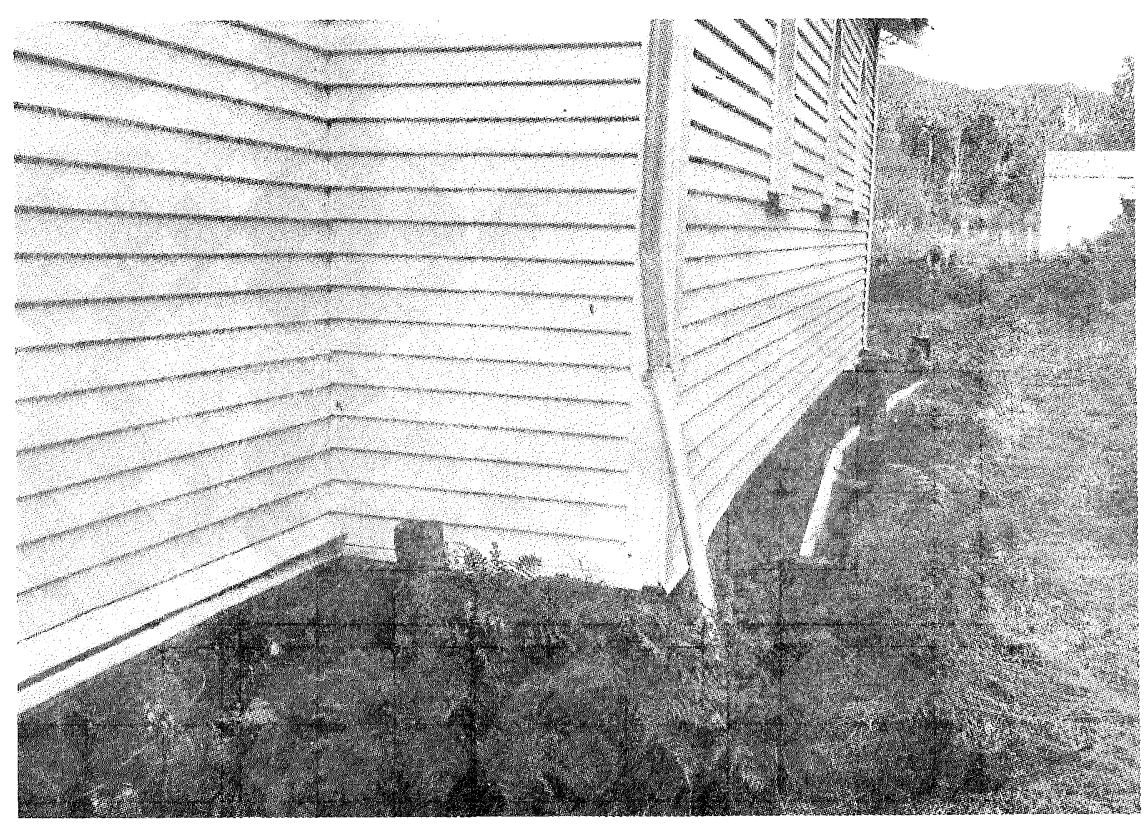

Fig. 20. Church, moved off its timber foundation piles 


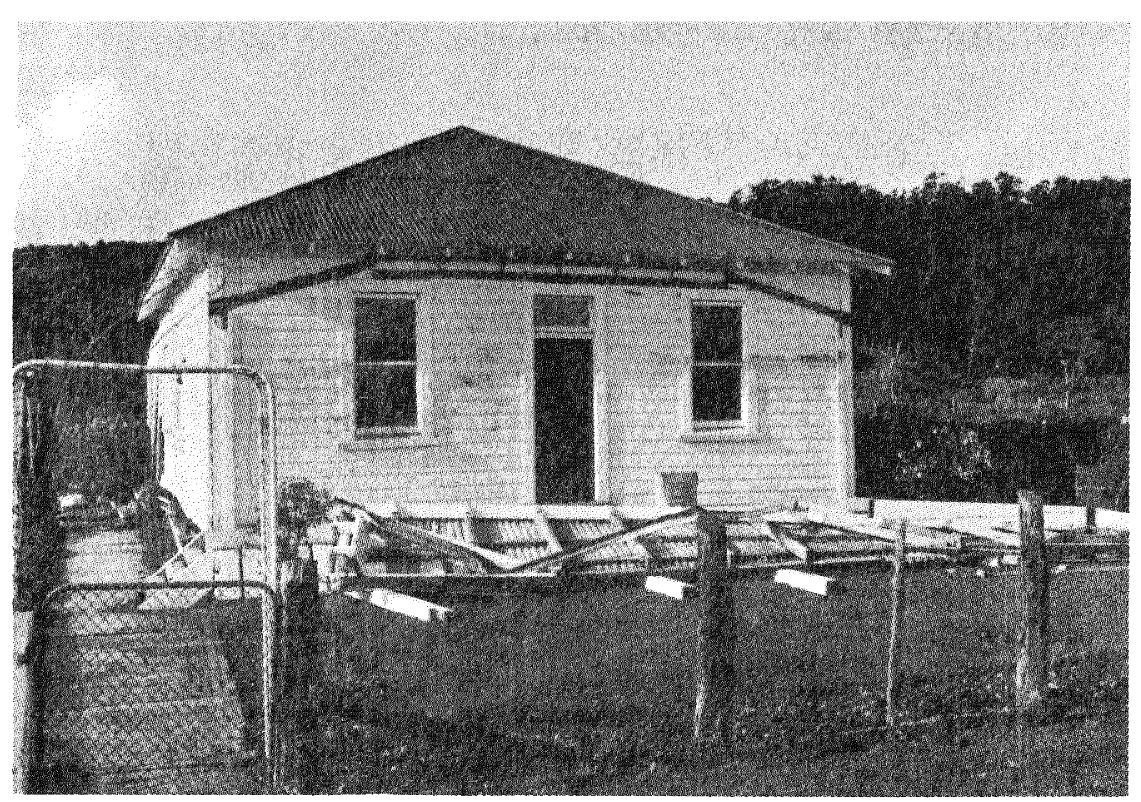

Fig. 21. Dwelling off piles, $1 \mathrm{~km}$ south of Inangahua Camp

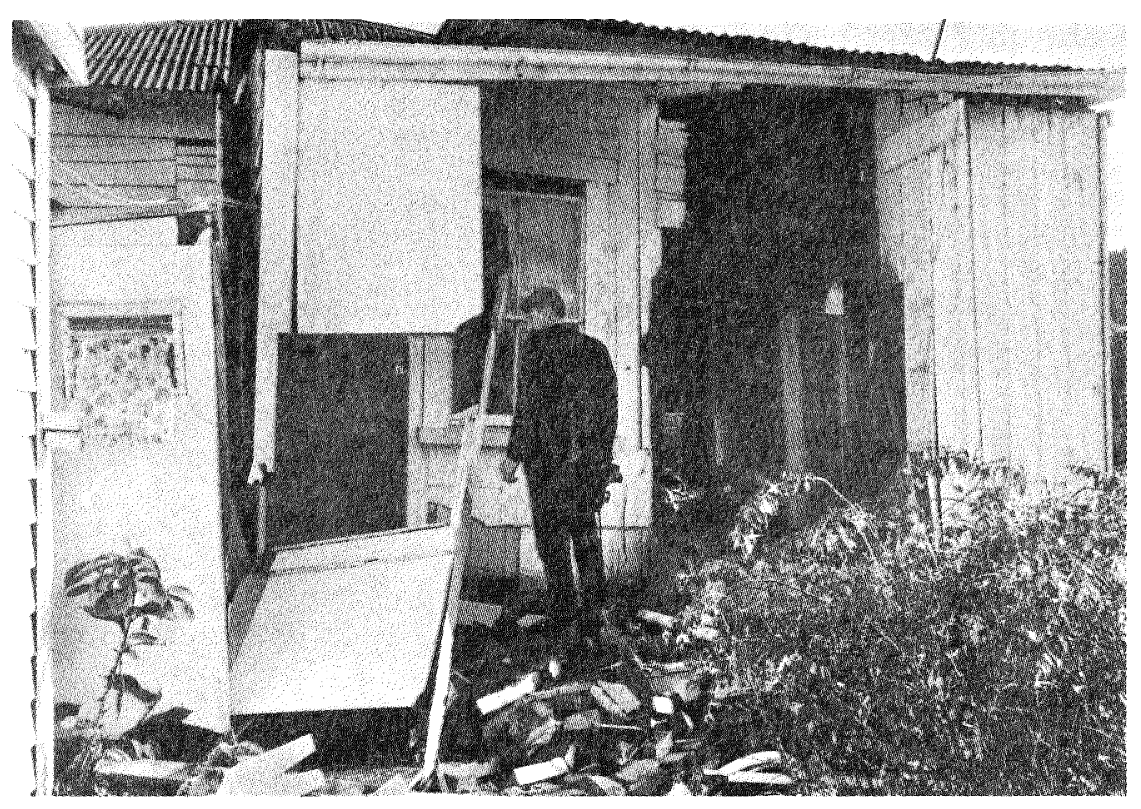

Fig. 22. rear of dwelling, fig 21

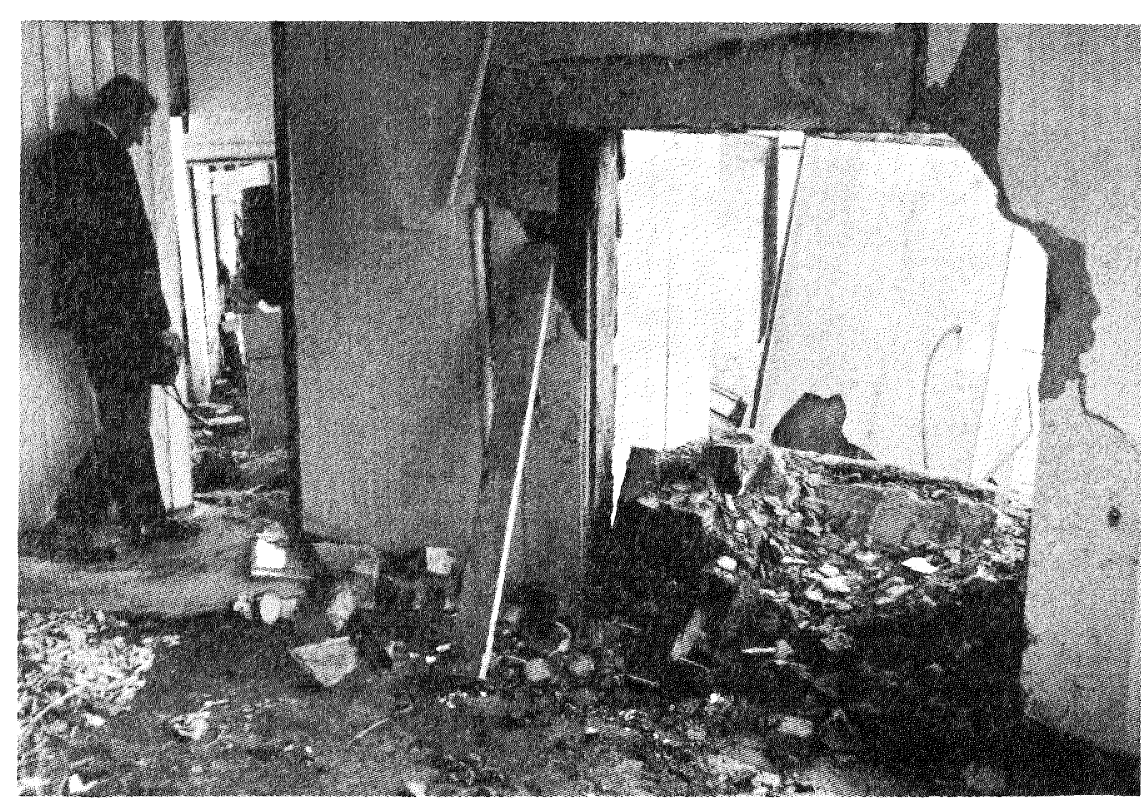

Fig. 23. Collapsed chimney and fireplace, fig. 21

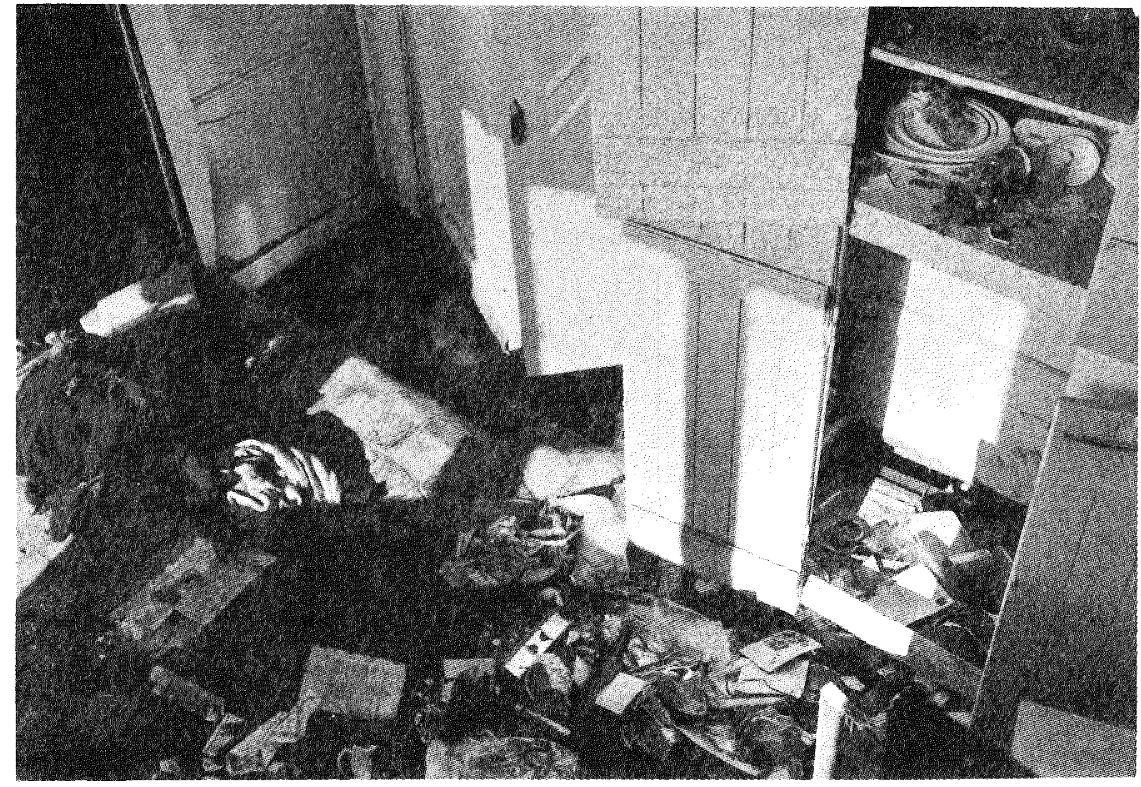

Fig. 24. Debris in pantry of dwelling of fig 21 


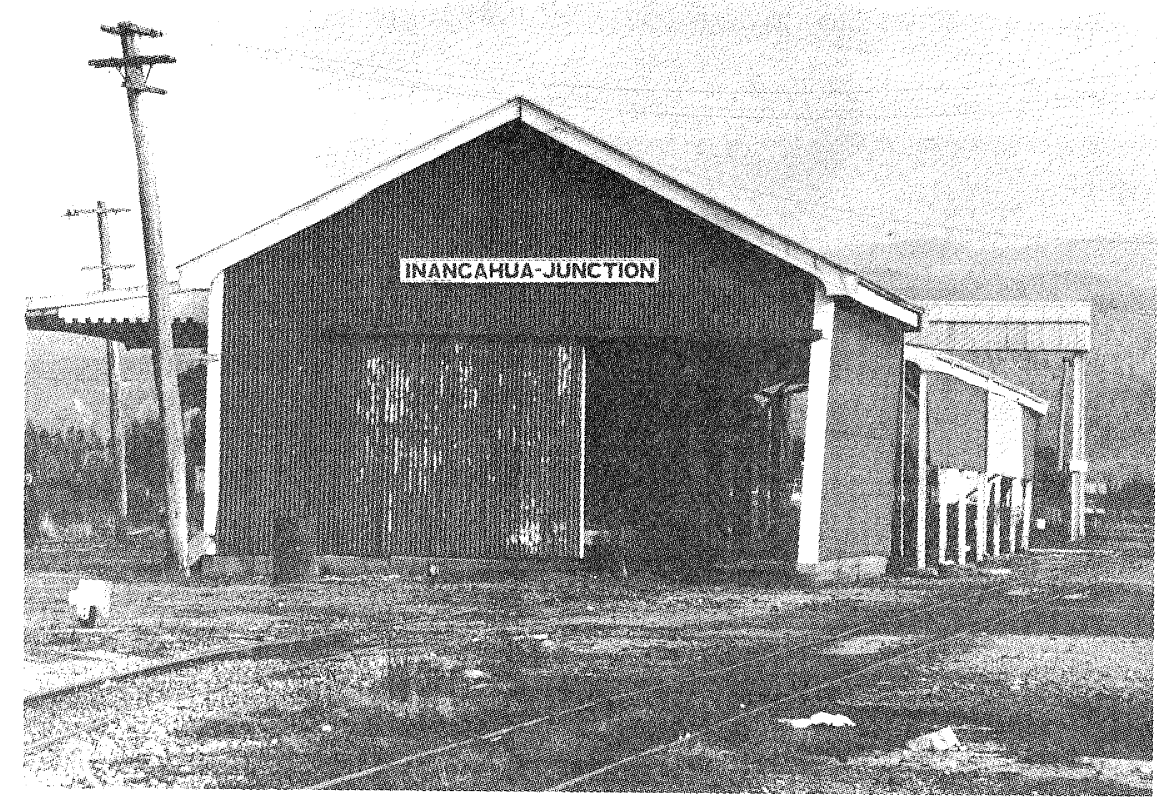

Fig. 25. Inangahua Junction railway station building

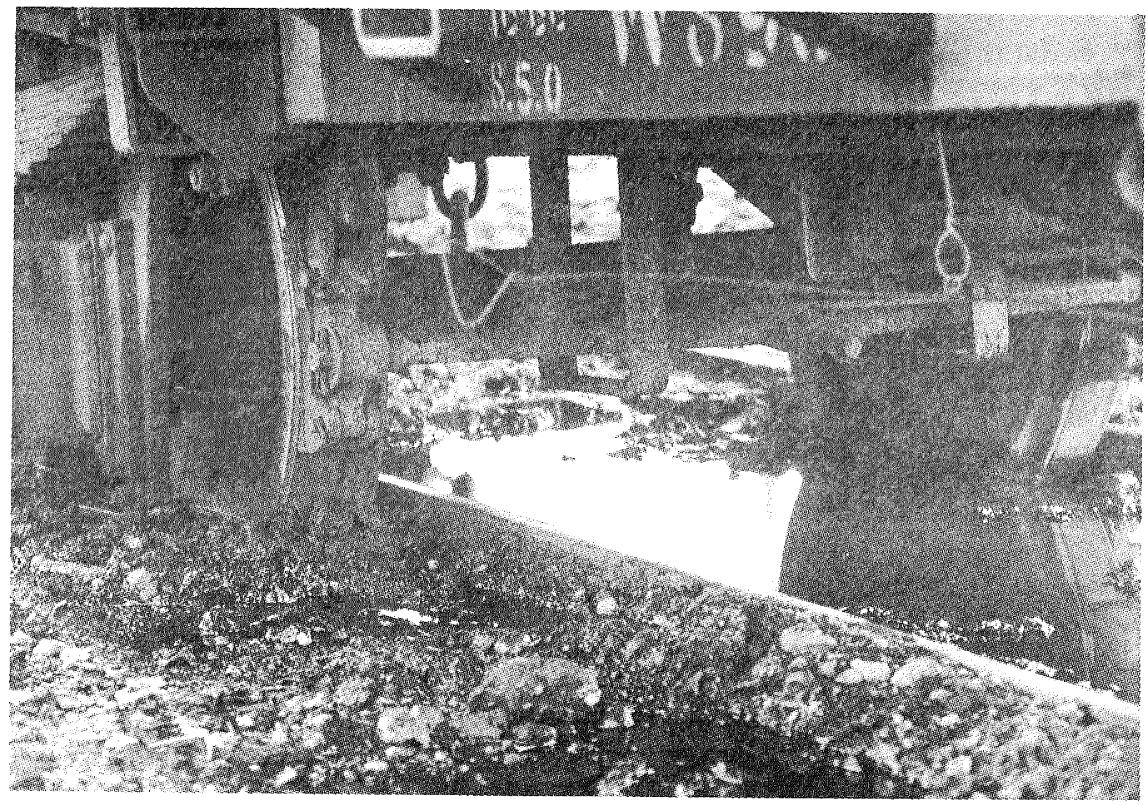

Fig. 26. Railway wagon displaced off rails

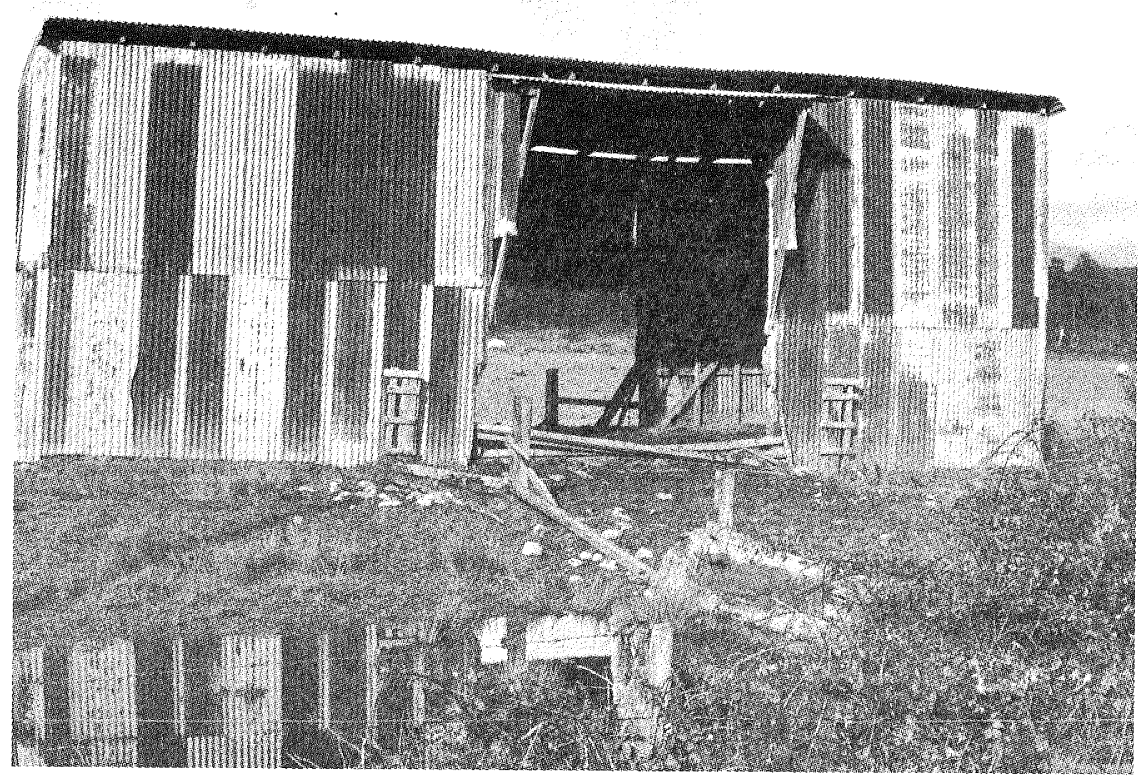

Fig. 27. Inangahua Junction. Shed on line of fault movement

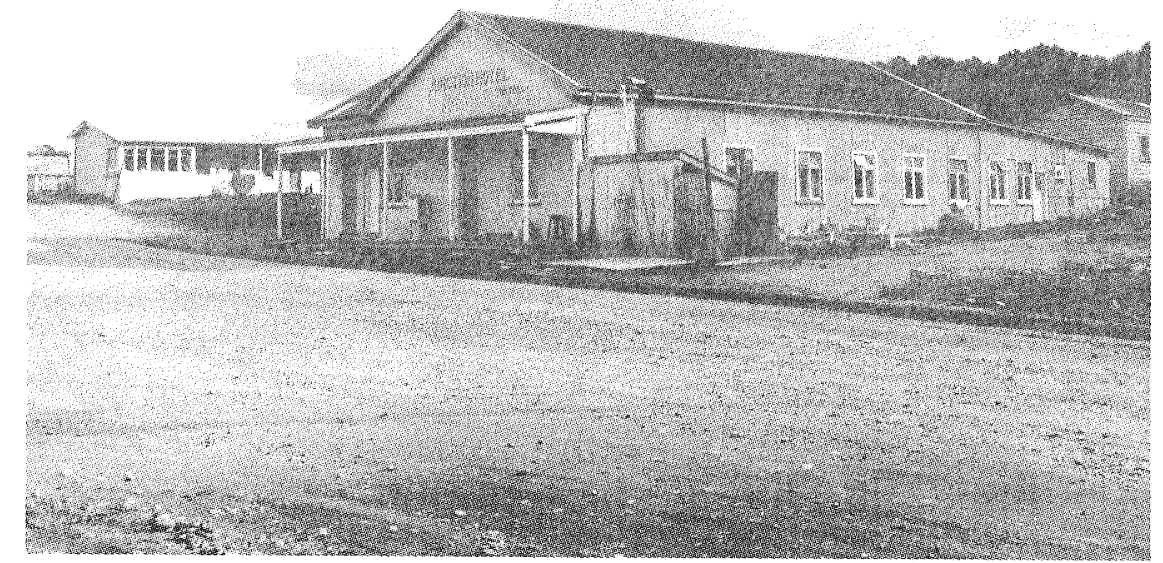

Fig. 28. Building at base of landslide and on fault line 


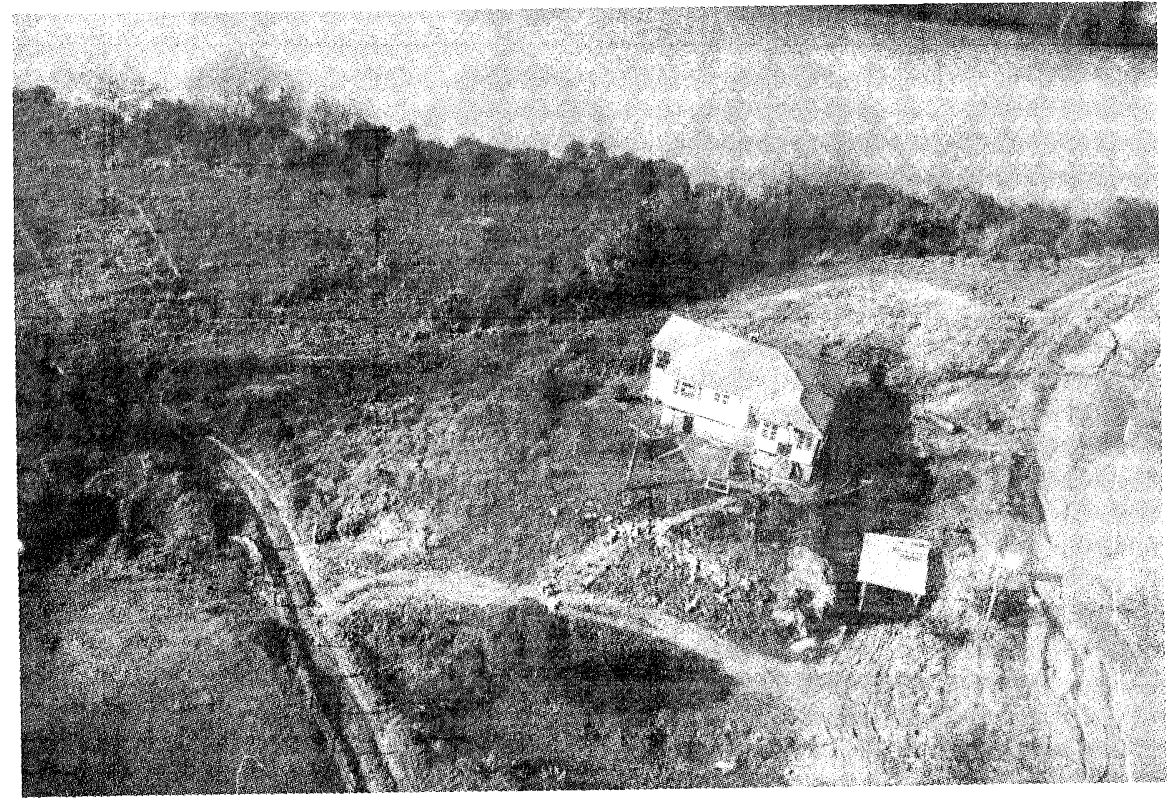

Fig. 29. Dwelling on earth movement, $4 \mathrm{~km} \mathrm{w.n.w.} \mathrm{Of} \mathrm{Ing'} \mathrm{Camp}$

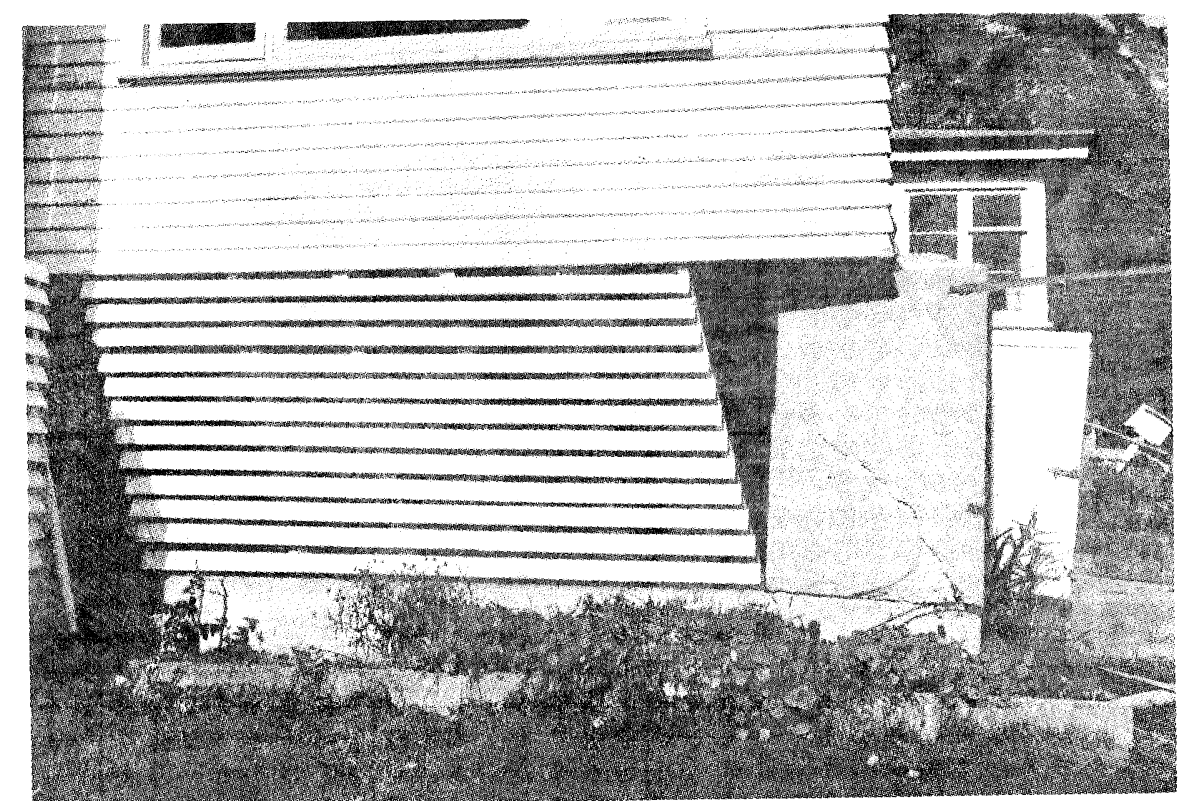

Fig. 30. Dwelling of fig. 29. movement at foundations

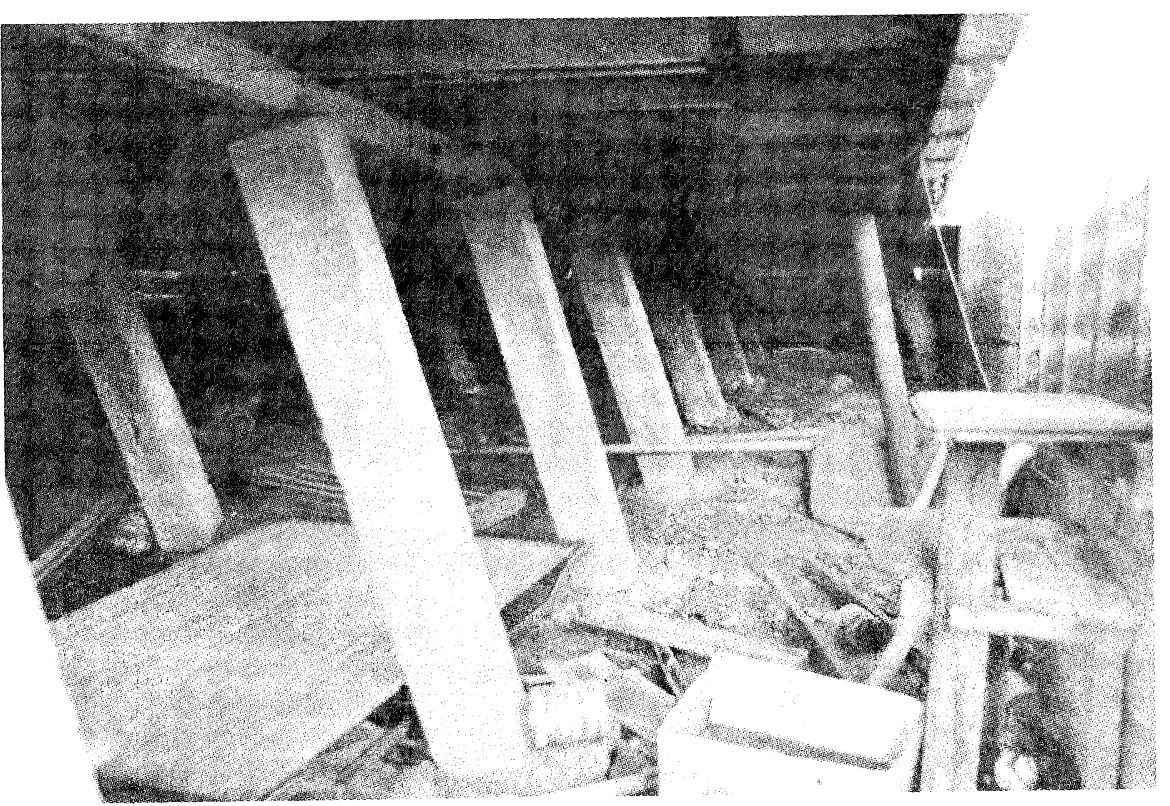

Fig. 31. Foundation piles leaning, dwelling, fig. 29

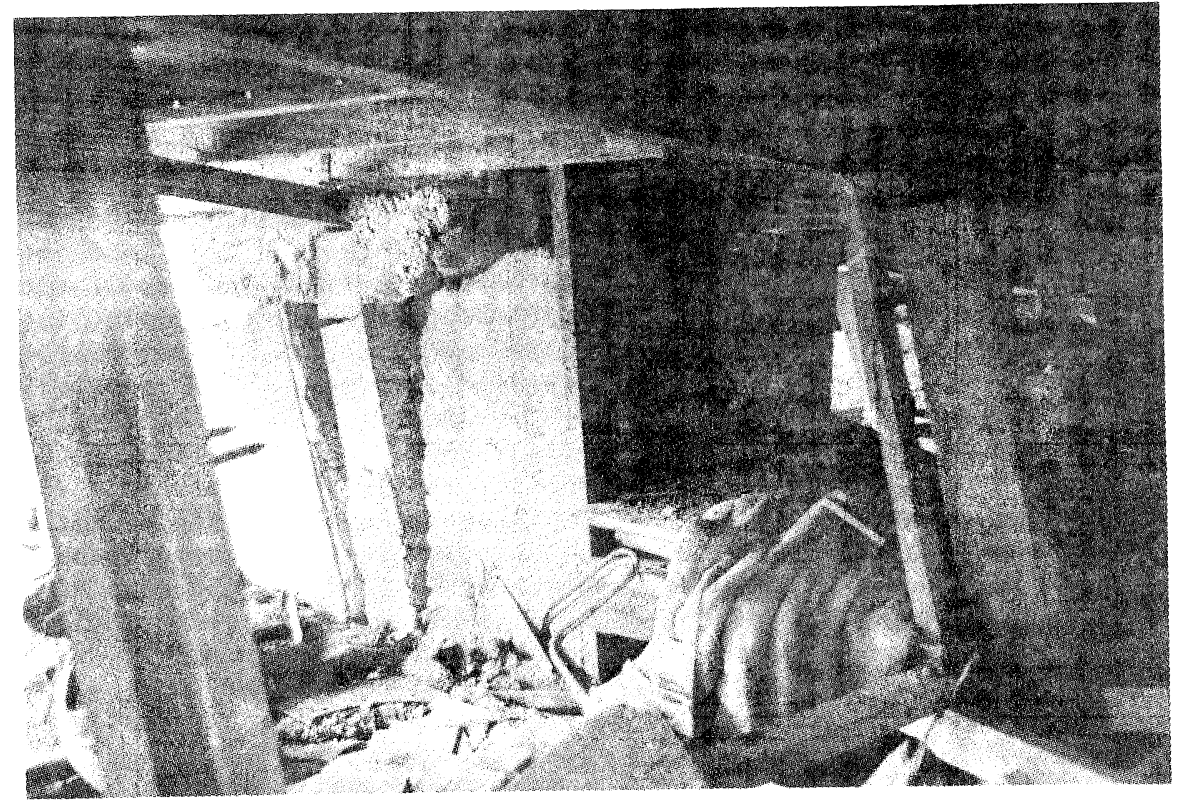

Fig. 32. Damage to chimney base, fig. 29 


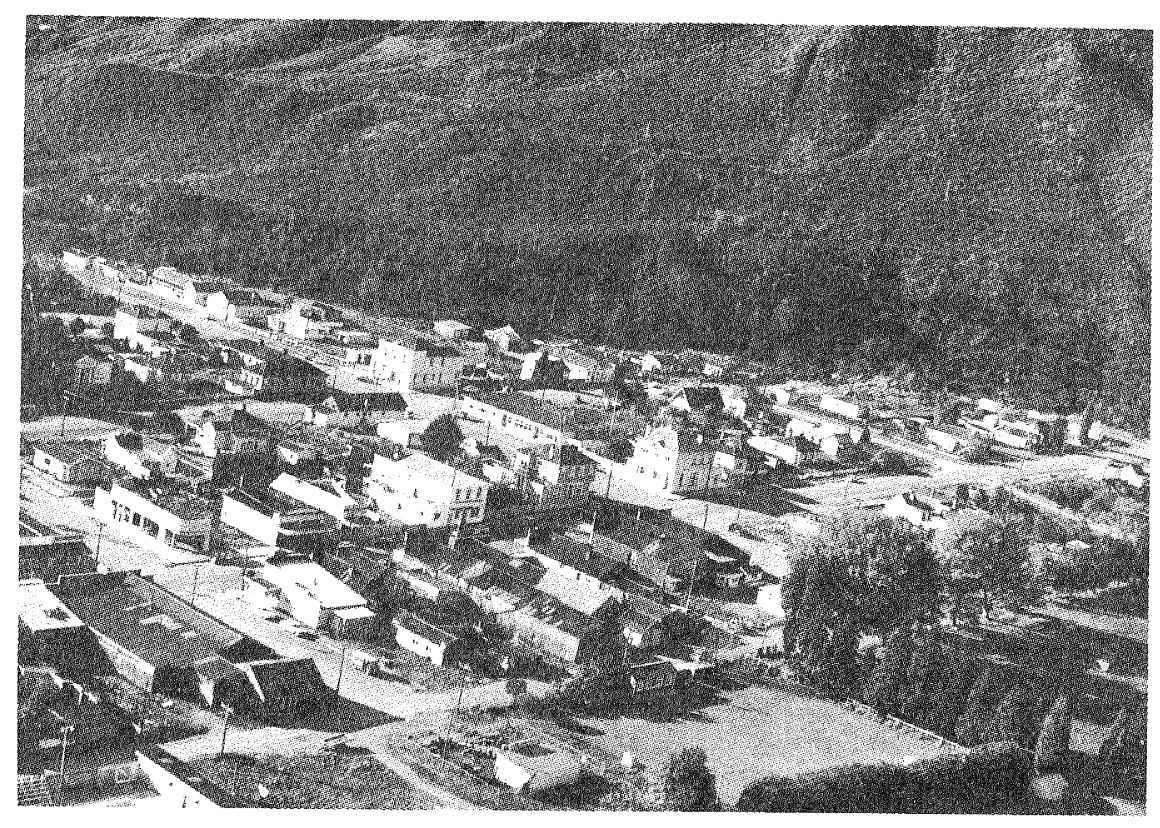

Fig. 33. View of Reefton, May 24, 1968

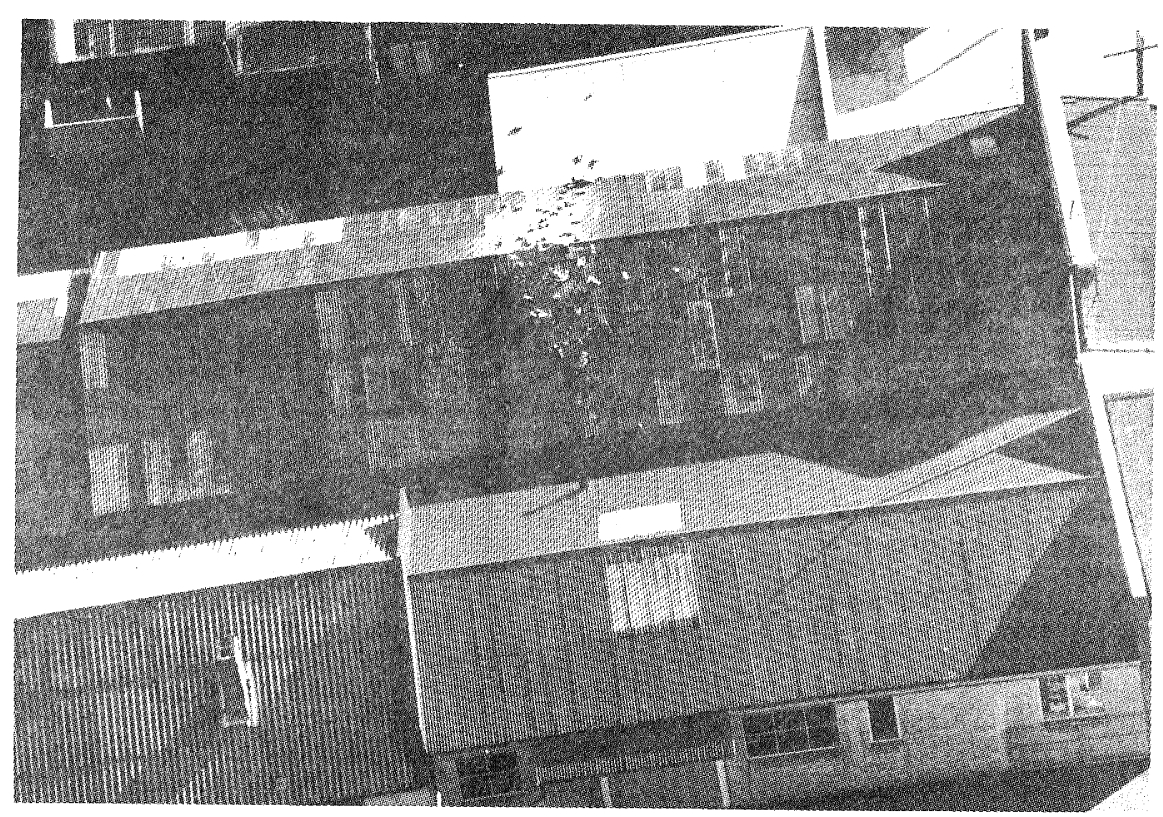

Fig. 34. Collapsed chimney, Reefton

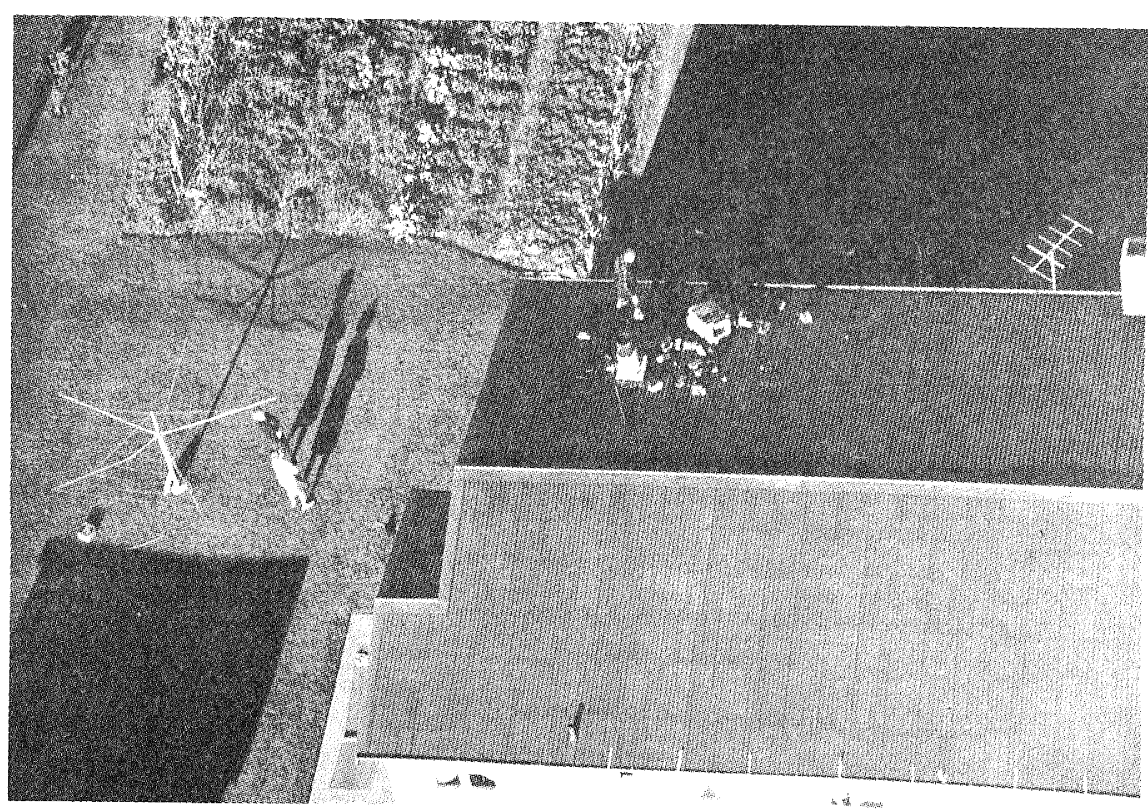

Fig. 35. A chimney collapse in Reefton

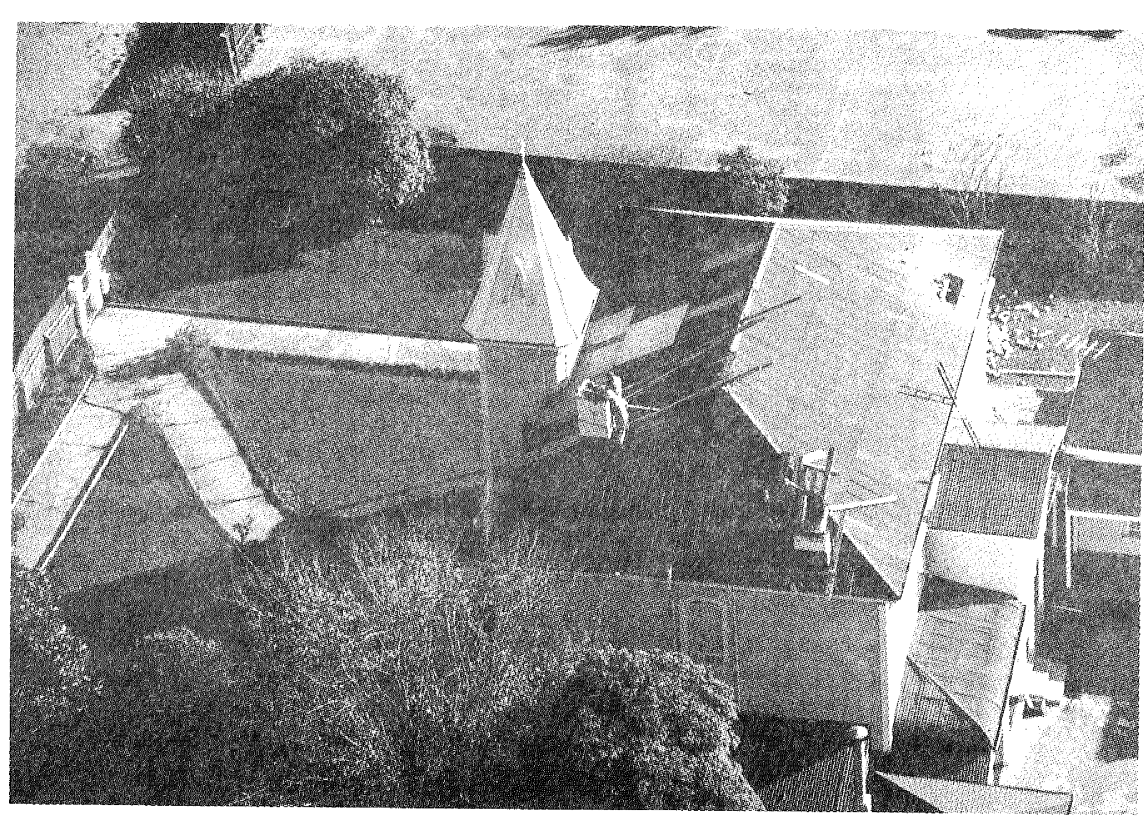

Fig. 36. Reefton, May 24, 1968, immediate work 